\title{
Information and Logistic Foundations of Pedagogical Education Design and Content Education
}

\author{
Vera K. Vlasova ${ }^{1}$, Galia I. Kirilova ${ }^{1}$ \& Alfiya R. Masalimova ${ }^{1}$ \\ ${ }^{1}$ Kazan (Volga region) Federal University, Kazan, Russia \\ Correspondence: Vera K. Vlasova, The Institute of Psychology and Education, Kazan Federal University, \\ Kremlyovskaya Street 18, Kazan, 420008, Russia. E-mail: v2ko@mail.ru
}

Received: December 29, 2014

doi: $10.5539 /$ res.v7n4p54

\author{
Accepted: January 22, 2015 Online Published: February 11, 2015 \\ URL: http://dx.doi.org/10.5539/res.v7n4p54
}

\begin{abstract}
The statement and solution of the design problem and implementation of pedagogical education content on the basis of information streams integration demands scientific and experimental justification which is carried out within the problem field of pedagogical science. In this regard, this article aims at developing an information-logistic model for designing and implementing the content of teacher education. The presented information-logistic model for designing and implementing the content of teacher education in the article presupposes the disclosure of the pedagogical system component structure as the base of information traffics differentiation. Materials of the article can be useful for the improvement of teachers' training system focused on their professional growth and their future competitiveness in the conditions of information society and innovative production development.
\end{abstract}

Keywords: pedagogical education, the information and logistic model, information specificity of the model, logistic specificity of the model, integration

\section{Introduction}

System transformations of modern society should be provided with basic changes in pedagogical education. The social order requires to form teacher's ability to search and analyze information, knowledge and experience of pedagogical activity in the information environment to train specialists for knowledge-intensive production (Zagvyazinsky \& Atakhanov, 2001; Ovechkin, 2005).

The article is aimed to analyze and study the foundations of pedagogical education design and content implementation within the context of information society and innovative production development. Its relevance is caused by the transition to new educational standards that regulate teachers' professional competence; it is necessary, first of all, for the realization of modern pedagogical process; secondly, for its complex improvement, and, finally, for the implementation of educational process subjects' own design activity.

Design and implementation of education content are supported by information streams understood from the position when interactions between educational organizations and society, between managing structures and structural divisions, between students and teachers and other subjects and sources of information significant for the educational process are provided with information (Zagvyazinsky, 2004). The set of information streams, their interrelations and necessary transformations have essential significance for pedagogical education content design and its realization in the updated educational process.

The analysis of the obtained progressive pedagogical experience, approaches and technologies successfully realized in various areas of social development is also valuable for education content updating. In pedagogical practice there is a tendency to apply the experience of systems productive development in the economic sphere performed on the basis of logistics as the theory of coordination and management of material and accompanying them information streams. At the same time it is necessary to carry out complete theoretical and methodological psychological and pedagogical scientific researches, pedagogical interpretation of logistic theory provisions for pedagogical education content design on the basis of information streams integration. The social order is implemented provided that logistic mechanisms in education content design are applied. They promote a stage-by-stage arrangement and streamlining of information exchange between educational organizations and a consumer. Information streams integration may become either a requirement or a verified internal essence of 
education content to guarantee the success of educational process realization implying its high-quality updating to a greater degree than the change of quantitative indicators, among which there is a period of training and a set of academic subjects.

\section{Literature Review}

The works of such scientists as Zagvyazinsky (2004), Mukhametzyanova (2009), Novikov (2000) devoted to integration processes of educational system development have become the most significant in revealing leading approaches, procedures and technologies of pedagogical education content design; Leontyev (1983) and Rubenstein's (1989), Kalimullin and Vinogradov (2012) researches deal with understanding of activity and personality; Gershunsky (2001), Kolesnikova (2005), Slastenin (2002) considered relevant and positive transformations of modern education content.

Within the problem field of pedagogical science there are ideas that reveal opportunities and prospects of information streams integration. First of all, these are basic provisions of educational logistics (Denisenko, 2003; Livshits, 2006; Vlasova, 2010), grounds and ways of information and communication technologies application in education (Ivshina, 2006; Lavina, 2011; Robert, 2010, etc.), conditions of information and education environment creation and realization (Kirilova, 2008; Mukhametzyanov, 2006, etc.), didactic systems of specialists' innovative training in the sphere of information (Nureyev, 2005; Ovchinnikova, 2009, etc.), ways of document flow arrangement on the basis of information and information streams (Drescher, 2005; Konarzhevsky, 2000; Vlasova \& Kirilova, 2012, etc.).

\section{Results and Discussions}

\subsection{Information Specificity of the Model}

The information specificity of the model aimed to design and implement pedagogical education content suggests that there should be applied the streams of external and internal contours relating respectively to innovative and traditional professional and educational infrastructures of pedagogical education. At the same time information streams that provide an internal contour reflect well timed and high-quality formation of each competence within the structure of pedagogical education content. Information streams providing an external contour are aimed to take into account innovative changes in the social order, and obtained educational experience. Thus, information specificity is revealed in the openness of educational process. The openness is defined by a constant exchange of subjective and objective information between internal components of teacher's training system and the outside world.

\subsection{Logistic Specificity of the Model}

Logistic specificity of the model shows itself in the variability of education content which is required by changing conditions of information society and innovative production development: future teachers work on real-life problems taken from the environment that is external for educational process in addition to ones that are typical for just educational situations. Students gain knowledge not only from their teacher, they analyze possible problems, participate in their discussion in the context of real-life situations; they work with external information bases to choose and make decisions, learn to apply critical thinking and be responsible for the decision chosen. Thus the integration between information streams of external and internal contours is carried out.

The advantage that is provided by pedagogical education content design on the basis of information streams integration consists in synchronization of both external contour streams the elements of which impact the process of pedagogical education content updating and forming a basis for design, development and promotion of innovations in educational process, and information streams of an internal contour which include content bearing levels of innovative processes application in an educational institution.

\subsection{The Model Implementation Conditions Having a Logistic Basis}

The first group of conditions that have a logistic basis is the following: a) the goals and content of modern teachers' training aimed to provide future pedagogues with knowledge that will meet the demand by the time of graduation; the emphasis is placed on the principle of activity and cognitive advancing; b) effective selection of forms and methods to actualize educational experience and abilities of a future teacher for the purpose to single out priority competences in the structure of a social order; thus the emphasis is laid on the principle of a real demand and competitiveness of the personality; c) timeliness and quality of feedback when the process of planning takes place; the emphasis is placed on the principle of system interactions and environment improvement. 


\subsection{The Model Implementation Conditions Having an Information Basis}

The second group of conditions that have an information basis is: a) the coherence of the training material with the algorithm of its delivering at the time of pedagogues' knowledge formation; knowledge should meet the demand by the time of graduation; the emphasis is placed on the principle of activity and cognitive advancing; $b$ ) relevance of the training material on the basis of objective information with the view to single out priority competences in the structure of a social order; thus the emphasis is laid on the principle of an actual demand and competitiveness of the personality; c) the specificity of pedagogical education content when the process of planning takes place on the basis of its information and environmental features; the emphasis is placed on the principle of system interactions and environment improvement.

The instrument of pedagogical education content implementation reflecting its information and logistic specificity is a network graph which presents the components of education content in their integrative connections and volumes offered for mastering within certain intervals of time. On its basis the network planning is carried out and the demanded degree of innovation and timeliness of updating of education content is monitored.

\begin{tabular}{|c|c|c|c|c|c|}
\hline \multicolumn{6}{|c|}{ Methodological foundations of design and implementation } \\
\hline \multicolumn{6}{|c|}{$\begin{array}{l}\text { Information streams are understood from the position when interactions between educational organizations and society, between } \\
\text { managing structures and structural divisions, between students and teachers and other subjects and sources of information } \\
\text { significant for the educational process } \\
\text { Significant tendencies are connected with the transition from the accumulation of knowledge towards the development of } \\
\text { education activity experience and pedagogical design in pedagogical education. } \\
\text { Information and logistic approach: unites and pedagogically interprets ideas of information and environmental and logistic } \\
\text { approaches, and is urged to provide interaction and interrelation of information streams for timely and high-quality formation of } \\
\text { competences, their coordinated realization and necessity for innovative production. } \\
\text { The principles of design and implementation revealed in integrative interaction: } \\
\text { - principle of a real-life demand and competitiveness (integration of innovative production and education), } \\
\text { - activity-based and cognitive advancing (integration of science and education) principle, } \\
\text { - principle of system interactions and improvement of the environment (integration of the social sphere and education). }\end{array}$} \\
\hline \\
\hline \multicolumn{6}{|c|}{ Theoretical bases of design and implementation } \\
\hline \multirow{5}{*}{\multicolumn{2}{|c|}{$\begin{array}{l}\text { Grounds } \\
\text { of information } \\
\text { streams } \\
\text { classification } \\
\text { - structure of } \\
\text { pedagogical system, } \\
\text { - external and } \\
\text { internal character of } \\
\text { information }\end{array}$}} & \multirow{5}{*}{\multicolumn{4}{|c|}{$\begin{array}{l}\text { Structure of a pedsystem } \\
\text { Purposes and motives }\end{array}$}} \\
\hline & & & & & \\
\hline & & & & & \\
\hline & & & & & \\
\hline & & & & & \\
\hline \multicolumn{6}{|c|}{ Scientific and methodical bases of design and implementation } \\
\hline \multirow{2}{*}{\multicolumn{4}{|c|}{$\begin{array}{l}\text { Pedagogical conditions of pedagogical education } \\
\text { content design are singled out on the basis of the leading } \\
\text { logistic provisions; they reflect the productivity of } \\
\text { singled out information streams application; they reveal } \\
\text { the principles of pedagogical education content design } \\
\text { implementation: } \\
\text { - provision of the required content of education in full } \\
\text { and guarantee of its necessary quality; } \\
\text { - specification of design at each of levels of the contents } \\
\text { and regulation of its quantity, necessary for mastering; } \\
\text { - accounting of individual demands of the specific subject } \\
\text { of educational process. }\end{array}$}} & \multicolumn{2}{|c|}{$\begin{array}{l}\text { Pedagogical conditions of pedagogical education content implementation. } \\
\text { Conditions having logistic basis: } \\
\text { - the necessity of purposes and content of teachers' training; } \\
\text { - the efficiency of forms and methods selection; } \\
\text { - the timeliness and quality of feedback when the process of planning is } \\
\text { implemented } \\
\text { Conditions having information basis: } \\
\text { - tele coherence of the training material content with the algorithm of its } \\
\text { delivering; } \\
\text { - the relevance of the training material on the basis of objective information; } \\
\text { - the specificity of pedagogical education content at the implementation of own } \\
\text { planning process. }\end{array}$} \\
\hline & & & & \\
\hline $\begin{array}{l}\text { inform. } \\
\text { streams }\end{array}$ & \multicolumn{2}{|c|}{$\begin{array}{c}\text { content of preparation } \\
\text { profile }\end{array}$} & \multicolumn{3}{|c|}{$\begin{array}{l}\text { levels of pedagogical education content } \\
\text { content of an educational } \\
\text { content of the } \\
\text { subject } \\
\text { academic subject }\end{array}$} \\
\hline standard & \multicolumn{2}{|c|}{$\begin{array}{l}\text { the structure of } \\
\text { necessary competences } \\
\text { according to the training } \\
\text { profile (the map of } \\
\text { competences) }\end{array}$} & \multicolumn{2}{|c|}{$\begin{array}{l}\text { the list of } \\
\text { competences after } \\
\text { studying a discipline }\end{array}$} & $\begin{array}{l}\text { fter passing of information along each } \\
\text { the list of goals, coordination of the } \\
\text { subject, designation of a problem } \\
\text { situation, formulation of an } \\
\text { educational problem }\end{array}$ \\
\hline cognitive & \multicolumn{2}{|c|}{$\begin{array}{l}\text { the list of disciplines } \\
\text { realizing necessary } \\
\text { competences }\end{array}$} & \multicolumn{3}{|c|}{$\begin{array}{l}\text { the list of educational the list of basic concepts, updating } \\
\text { modules and topics of of available knowledge, the project } \\
\text { of future educational actions }\end{array}$} \\
\hline methodical & \multicolumn{2}{|c|}{$\begin{array}{l}\text { the approximate list of } \\
\text { methods and techniques } \\
\text { of an educational process } \\
\text { according to the training } \\
\text { profile }\end{array}$} & \multicolumn{2}{|c|}{$\begin{array}{l}\text { educational and } \\
\text { methodical complexes } \\
\text { of academic } \\
\text { disciplines }\end{array}$} & $\begin{array}{l}\text { forms of communicative } \\
\text { interaction (frontally, in groups, in } \\
\text { pairs), forms of work at a lesson }\end{array}$ \\
\hline technologica & \multicolumn{2}{|c|}{$\begin{array}{l}\text { the list of laboratories, } \\
\text { offices; EOR of forms of } \\
\text { training (full time, } \\
\text { distant, etc.) }\end{array}$} & \multicolumn{2}{|c|}{$\begin{array}{l}\text { technological maps } \\
\text { (means of training, } \\
\text { interactive) }\end{array}$} & $\begin{array}{l}\text { working methods, information } \\
\text { sources, audiovisual and technical } \\
\text { means of training and presentation }\end{array}$ \\
\hline regulatory & \multicolumn{2}{|c|}{$\begin{array}{l}\text { educational maps of the } \\
\text { teacher (individual work } \\
\text { loadings) }\end{array}$} & \multirow{2}{*}{\multicolumn{2}{|c|}{$\begin{array}{l}\text { the list of conditions } \\
\text { aimed to realize } \\
\text { disciplines, forms and } \\
\text { means of control } \\
\text { the list of questions } \\
\text { and tasks of the } \\
\text { discipline }\end{array}$}} & $\begin{array}{l}\text { specific skills for work, options of } \\
\text { new knowledge application in } \\
\text { practice }\end{array}$ \\
\hline reflexive & \multicolumn{2}{|c|}{$\begin{array}{l}\text { analytical and } \\
\text { forecasting map of the } \\
\text { training profile }\end{array}$} & & & $\begin{array}{l}\text { types of oral and written } \\
\text { independent works and exercises, } \\
\text { ways of feedback }\end{array}$ \\
\hline
\end{tabular}

Figure 1. Information and logistic model of pedagogical education content implementation 


\section{Conclusion}

The information and logistic model of pedagogical education design and implementation developed by us assumes to reveal the component structure of a pedagogical system as the basis of information streams differentiation. At the level of goals and motives the specification of education content is carried out within the structure of standard information, and at the level of education content composition and structure is implemented within the structure of cognitive information that is revealed in external and internal contours through the information about competences that are in demand and in the process of forming; at the level of forms, methods and tutorials, specification is carried out within the structure of methodical and technological information; at the level of quality ensuring (result) and feedback the specification is carried out in the structure of regulatory and reflexive information.

The combination of pedagogical conditions for pedagogical education content design presented in the model has been revealed on the basis of leading logistic provisions interpreted from the position of an education system and educational process and reflects the productivity of singled out information streams application: a) the provision of the demanded education content in full and guarantee of its necessary quality selected from the point of view of science, education and production integration; b) specification of design at each level of the content (a profile of training, an academic subject, a theme and mastered competences) and regulation of its quantity necessary for mastering from the position of reasonable prospects and a zone of a near-term development; c) the accounting of individual inquiries of the specific subject of educational process - including the teacher and the student, and accurate following of the standards regulating the educational process.

The first group of conditions aimed at pedagogical education content implementation includes the conditions that have a logistic basis. The second group of conditions aimed at pedagogical education content implementation has an information basis.

\section{Acknowledgments}

The work is performed according to the Russian Government Program of Competitive Growth of Kazan Federal University

\section{References}

Denisenko, V. A. (2003). Fundamentals of educational logistics. KSU: Kaliningrad University.

Drescher, Y. N. (2005). Organization of information production (p. 245). Studies allowance. Moscow: GRAND: Fair Press.

Gershunsky, B. S. (2001). Education as a religion of the third millennium: The harmony of knowledge and faith (p. 128). Moscow: Pedagogical Society of Russia.

Ivshina, G. V. (2006). New information technologies in the educational process. Kazan: KSU.

Kalimullin, A. M., \& Vinogradov, V. L. (2012). Vocational guidance of school students: The state of the problem and means of its solution. Education and self-development, 6, 148-155.

Kirilova, G. I., \& Volik O. N. (2008). Actual questions of creative education as a basis for personal development in the information society. Educational Technology \& Society (Educational Technology \& Society), 11, 4.

Kolesnikova, I. A., \& Gorchakova-Siberskaya, M. P. (2005). Pedagogical design: Proc. manuals for higher (p. 288). Moscow: Pub. center "Academy”.

Konarzhevsky, Y. A. (2000). Management and Intraschool management. Moscow.

Lavina, T. A. (2011). Formation of competence of students of pedagogical high school in the field of information and communication technologies (p. 309). Stockholm: CHPGU.

Leontiev, A. N. (1983). Selected psychological works (Vol 2, p. 320). Moscow: Pedagogy.

Livshits, V. M. (2006). On the history of the study of wave training. Questions psychology, 6, 160-162.

Mukhametzyanov, I. S. (2006). Pathophysiology of informatization of education: Sanitation and medical aspects of education informatization (p. 148). Izhevsk: Publishing house "Udmurt State University".

Mukhametzyanova, G. V. (2009). The main trends in the development of vocational education.

Novikov, A. M. (2000). Russian education in the new era: The paradoxes of heritage, vectors development (p. 270). Moscow: Egves.

Nureyev, N. K. (2005). Didactic space training of competent professionals in the field of software engineering (p. 
244). Kazan: Univ Casasco University.

Ovchinnikova, I. G. (2009). Educational information environment for training IT professionals using distance learning technologies (p. 164). Magnitogors: Magnitogorsk State University.

Ovechkin, V. P. (2005). The content of technology education: Rationale, principles, design criteria (p. 220). Moscow: Izhevsk, RIP Regular and chaotic dynamics.

Robert, I. V. (2010). Theory and methods of education informatization (3rd ed., p. 356). Moscow: ERI RAE.

Rubinstein, S. L. (1989). Fundamentals of General Psychology (p. 488). Moscow: Pedagogy.

Slastenin, V. A. (2002). Pedagogy (p. 576). Moscow: Academy.

Vlasova, V. K. (2010). Logistic bases of information streams management in the modern information educational environment. The Bulletin of Kazan state power engineering university, 2, 146-151.

Vlasova, V. K., \& Kirilova, G. I. (2012). Algorithms of monitoring and control of educational process in the context of electronic educational resources. Quality Innovations Education, 7, 36-40.

Zagvyazinsky, V. I. (2004). Modeling the structure of social and pedagogical design. Herald high school, 9, 21-25.

Zagvyazinsky, V. I., \& Atakhanov, R. (2001). Methodology and methods of psycho-pedagogical research. Moscow: Academy.

\section{Copyrights}

Copyright for this article is retained by the author(s), with first publication rights granted to the journal. This is an open-access article distributed under the terms and conditions of the Creative Commons Attribution license (http://creativecommons.org/licenses/by/3.0/). 